\title{
Simulation of Return Flow in Restricted Navigation Channel for Barge-tow Movements
}

\author{
S. N. Das ${ }^{1}$, Samir K. Das ${ }^{2, *}$ and J. N. Kariya ${ }^{3}$ \\ ${ }^{I}$ Mathematical Modelling for Coastal Engineering Division, Central Water and Power Research Station, Khadakwasla, \\ Pune-411024, India \\ ${ }^{2}$ Defence Institute of Advanced Technology (DU), Girinagar, Pune-411025, India; formerly, Senior Research Officer, \\ Mathematical Modelling Centre, Central Water and Power Research Station, Khadakwasla,Pune - 41102, India \\ ${ }^{3}$ Flow Science Software Pvt. Ltd., Pune-411029, India
}

\begin{abstract}
Simulations of barge-tow movement in the sub-critical range along the Illinois River near Kampsville are performed to determine the return flow (RF) characteristics for upstream and downstream bound barge-tows. Simulations are carried out using the OpenFOAM ${ }^{\circledR}$ based CFD software for six barge-tow configurations considering two-dimensional shallow water equation. The RF velocities are simulated for $0 \mathrm{~s}$ to $100 \mathrm{~s}$ at an interval of $10 \mathrm{~s}$ at nine different locations, taken across the river from vessel to bank for upstream and downstream bound barge-tows. The computed RF velocities at these points between the bow and the bank are analyzed and compared with the observed field data for identical conditions. The simulated RF velocity agrees well with the computed RF velocity of Hochestein and Adams, and Maynord and Siemsen, except closer to the barge-tow. Model simulation shows that the RF profiles (lateral velocity distributions transverse to vessel movement) vary with time and the length of the vessel. To understand the associated phenomena, drawdown and squat are computed using empirical formulations given by earlier researchers. The simulated result clearly indicates the location of the zero velocity point for downstream bound barge-tows. The present study would be helpful to hydraulic engineers, planners and biologists to predict RF hydrodynamic in a restricted channel.
\end{abstract}

Keywords: Return flow, restricted waterway, CFD, OpenFOAM, Navier-Stokes equation, barge-tow, Illinois river, navigation channel, Froude number.

\section{INTRODUCTION AND BACKGROUND}

The passing of a ship in a restricted channel exerts forces on the waterway, which in turn change the ambient flow pattern and associated hydrodynamics. This results in the generation of surge waves; return flow, squatting, drawdown, sediment re-suspension and bank scouring which are absent or not too prominent in open and unrestricted channels. Depending on the channel geometry, the ship's speed and the blockage ratio, a ship navigates in one of three speed ranges, i.e., the subcritical, critical, or supercritical. The lower and upper critical speeds occur between the subcritical and critical flow regimes and critical and supercritical flow regimes respectively. This can be best described in terms of one dimensionless parameter, the Froude number. When a ship moves along a restricted waterway, it pushes water in front of its bow, generating a high-pressure zone, and at the same time a void is created behind the stern as a lowpressure zone. This causes water to flow from all directions to fill the void astern. In addition, the propellers of the ship suck a large amount of water beneath the keel and thrust the

*Address correspondence to this author at the Department of Applied Mathematics, Defence Institute of Advanced Technology (DU), Girinagar, Pune-411025, India; Tel: 91-20-24304081; Fax: 91-20-24389288;

E-mails: samirkdas@diat.ac.in; samirkumar_d@yahoo.com water in a direction opposite to the ship movement. All these flow conditions accelerate the water around the ship, causing an increase in the kinetic energy of the water while the potential energy drops. The velocity field produces a hydrodynamic pressure field along the length of the vessel which is similar to Bernoulli's effect where the kinetic and potential energy are balanced. The decrease in potential energy as well as pressure manifests themselves by a lowering of water level which is known as drawdown. As the velocity of water under the keel speeds up, there is a drop in pressure. Due to the decrease in pressure beneath the keel, a vertical force in the downward direction is exerted on the ship and as a result, the ship drops vertically down in the water. As a result of uneven pressure distribution throughout the hull of the ship, a moment about the transverse axis of the ship is generated, and the ship trims forward or aft. The overall decrease in the under-keel clearance forward or aft is called the ship squat. This squatting effect gives an impression that the ship moves with less freeboard. The ship may even strike the channel bed when the keel clearance is not enough. The water flowing around the wetted surface of the hull from bow to stern is known as return flow (RF) or backflow. The longitudinal velocity of the RF across the channel is not uniform; rather it varies in the space between the vessel and the bank. The strength of the RF velocity depends on the channel geometry, the ambient flow, the ship speed, the blockage factor and 


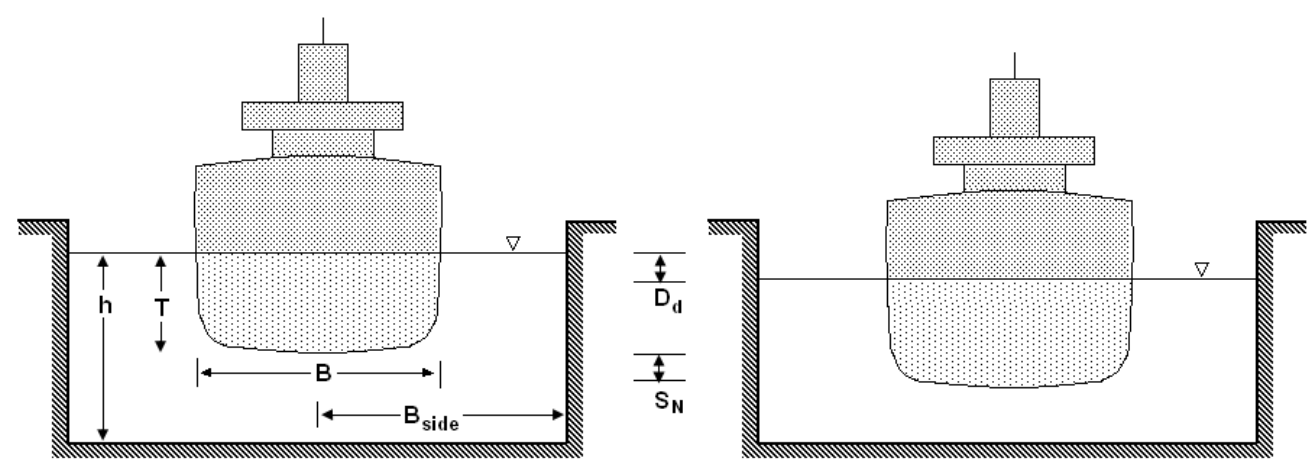

(a)

(b)

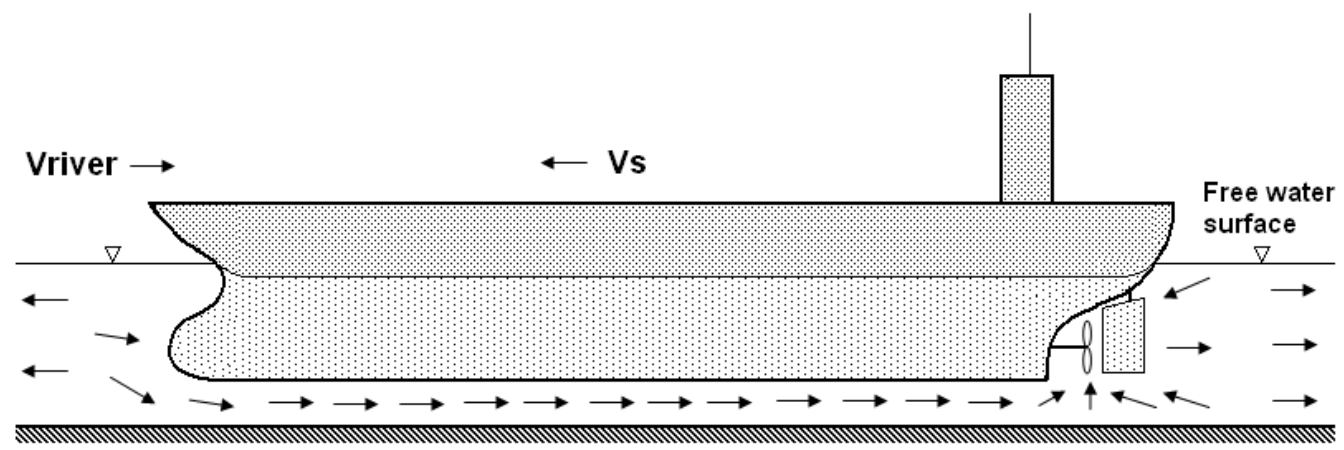

(c)

Fig. (1). Schematic diagram showing (a) vessel rest on still water, (b) drawdown and squat for moving vessel and (c) flow past under keel.

the ship's proximity to the bank. The irregular topography of the channel complicates the behavior by means of reflection, amplification and occasional resonance for a general river system. Figs. (1a-c) show the schematic diagram of (a) vessel at rest in still water (b) drawdown and squat for moving vessel and (c) flow under keel.

The return flow, drawdown and squatting are interrelated entities and a manifestation of the energy caused by the movements of the displaced water mass due to ship maneuvering in restricted waterways; these have been studied widely for various channel geometry and ship sizes. In subcritical speed ranges, steady flow prevails and the behaviour of a ship as it moves along a channel has been analyzed by Kreitner [1] by using Bernoulli's theorem and the continuity principle. Schijf [2], Tothill [3] and McNown [4] have studied the prediction of water-level depression and average RF on the basis of Bernoulli's equation and the equation of continuity. The flow becomes unsteady in the critical speed range and it has been studied by Constantine $[5,6]$, based on surge wave theory and the theory of characteristics. Constantine $[5,6]$ also discussed several hydrodynamic aspects induced by ship movements in subcritical and supercritical speed ranges. Balanin and Bykov [7] have presented an approximation for the water-level depression and return velocity. Sharp and Fenton [8], and Bouwmeester [9] developed a method for the calculation of the water-level depression and the RF in channels considering the conservation of mass and momentum. Bouwmeester [9] considered a trapezoidal channel and accounted for the water-level rise in front of the bow whereas Sharp and Fenton [8] considered a rectangular channel but neglected the effect of water-level rise in front of the bow. Schofield [10] examined the resistance and behaviour of ship navigation in restricted channels. His experimental work confirms that a self-propelled ship attains its apparent maximum speed in a restricted channel, irrespective of power and the speed. Further, resistance characteristics which are nonlinear in the critical speed range leads to the dissipation of excess energy by bank erosion. An excellent review and a comparison of the various methods presented by previous researchers are given by Blaauw and van der Knaap [11]. Existing methods for the determination of $\mathrm{RF}$ are based on the analytical treatment using either the conservation of energy or momentum and some empiricism. These analytical treatments are primarily based on the following conditions; uniform trapezoidal or rectangular channel cross-section, uniform ambient velocity and return velocity, and uniform water-level depression, and they neglect frictional losses. Bhowmik et al. [12] reviewed the work of Schijf and Jansen [13], Bouwmeaster [9], Blaauw and Knapp [11], and Hochstein and Adams [14] for the computation of average return velocity based on the concepts of conservation of mass, momentum or energy in connection with the movement of barge traffic in a narrow channel. Variations of RF between the barge and the bank have been studied by Simons et al. [15], Berger et al. [16], Hochstein and Adams [14], and Maynord and Siemsen [17]. Stockstill and Berger [18] described the waterway response to barge generated currents and waves with the aid of numerical modelling 
Table 1. Barge-Tow Configuration

\begin{tabular}{|c|c|c|c|c|c|c|c|}
\hline \multirow{2}{*}{ Name of Barge-Tow } & \multirow{2}{*}{ Direction } & \multirow{2}{*}{ Speed (m/s) } & \multicolumn{5}{|c|}{ Barge-Train } \\
\cline { 4 - 9 } & & & No. of Barge Units & Configuration & Length (m) & Beam (m) & Draft (m) \\
\hline \hline Sugarland & Upstream & 1.88 & 12 & $3 * 4$ & 42.1 & 12.8 & 2.29 \\
\hline Conti Karla & Upstream & 1.70 & 16 & $3 * 5+1$ & 34.8 & 10.5 & 2.34 \\
\hline Nicholas Duncan & Upstream & 1.52 & 9 & $3 * 3$ & 39.0 & 8.5 & 2.74 \\
\hline W.C. Norman & Downstream & 2.90 & 12 & $3 * 4$ & 33.5 & 10.4 & 2.74 \\
\hline Rambler & Downstream & 2.48 & 12 & $3 * 4$ & 27.4 & 9.1 & 2.74 \\
\hline Ardyce Randal & Downstream & 2.36 & 15 & $3 * 5$ & 44.2 & 14.6 & 2.74 \\
\hline
\end{tabular}

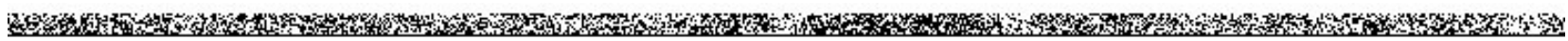

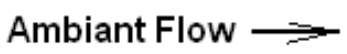

$\leftarrow$ Barge-tow Movement

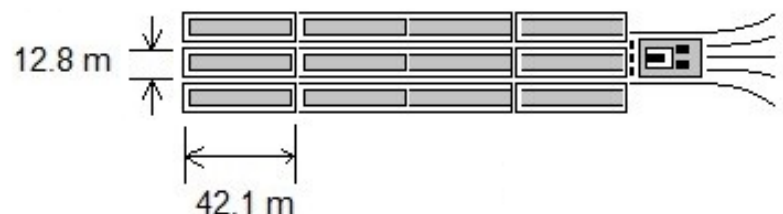

\section{WHA}

Fig. (2). Schematic diagram of Sugarland barge-tow configuration

where a moving pressure field is represented by the vessel's displacement. Field data collected at four sites along the Illinois River, viz., Kampsville, Apple River Island, Goose Island and Clarks Ferry (Bhowmik et al.) $[19,20]$ are analyzed and the return velocity distribution have been examined by Mazumder et al. [21] using an empirical model.

In the present paper, predictions of drawdown, squat and return velocity have been carried out for barge-tow movements in Illinois River at Kampsville site. Apart from computations based on the three previously developed formulas, two-dimensional simulations of RF on a water-plane for barge-tow movements have been carried out using the computational fluid dynamics (CFD) based OpenFOAM software [22], for the case when the vessel navigates along the centre line of a uniform rectangular channel with no-slip boundary condition. Simulations of six barge-tow movements at the Kampsville site on the Illinois River are carried out to examine the return flow profile characteristics in the sub-critical range. This paper examines draw down, squatting, velocity and pressure fields around the moving bargetow at different time instants.

\section{REVIEW OF FIELD DATA AND EMPIRICAL FORMULATIONS}

A significant amount of field data pertaining to bargetow movements at different sites on the Illinois River and Mississippi River was collected and these are reported by Mazumder et al. [23, 24] and Bhowmik et al. [12, 19, 20]. In the present study, the field data reported by Mazumder et al. [21] for the Illinois River near Kampsville site are taken for simulation purpose. A total of six events are considered in the present study, viz., three upstream bound barge-tows, i.e., Sugarland, Conti Karla and Nicholas Duncan; and three down stream bound barge-tows, viz., W. C. Norman, Rambler and Ardyce Randal. The wetted cross-sectional area, surface width, average depth and ambient velocity of the 
Table 2. Computed Drawdown for Upstream and Downstream Bound Barge-Tows

\begin{tabular}{|c|c|c|c|c|c|c|}
\hline \multirow[t]{2}{*}{ Barge-Tow } & \multirow[t]{2}{*}{ Direction } & \multicolumn{5}{|c|}{ Drawdown (m) } \\
\hline & & Hochstein and Adams (1989) & Dand and White (1978) & $\mathrm{Y}=5 \mathrm{~m}$ & $\mathrm{Y}=10 \mathrm{~m}$ & Averag \\
\hline Sugarland & Upstream & 0.011 & 0.035 & 0.038 & 0.019 & 0.026 \\
\hline Conti Karla & Upstream & 0.007 & 0.022 & 0.039 & 0.019 & 0.022 \\
\hline Rambler & Downstream & 0.021 & 0.049 & 0.061 & 0.030 & 0.040 \\
\hline Ardyce Randal & Downstream & 0.033 & 0.086 & 0.358 & 0.179 & 0.164 \\
\hline
\end{tabular}

river at Kampsville are $1331 \mathrm{~m}^{2}, 366 \mathrm{~m}, 3.64 \mathrm{~m}$ and $0.58 \mathrm{~m} / \mathrm{s}$ respectively. The barge-tow configurations, mentioned in Table 1, are based on Mazumder et al. [21]. A schematic diagram of Sugarland barge-tow is shown in Fig. (2). The detailed procedure of data collection can be obtained from Mazumder et al. [23, 24] and Bhowmik et al. [12, 19, 20]. In the following sub-sections, we revisit earlier formulations on drawdown, squatting and RF velocity.

\subsection{Drawdown}

Generally, the drop in water level or drawdown $\left(D_{d}\right)$ is more around the vessel and it decreases with the increase in distance from the vessel to bank (Gelencser) [25]. The channel constriction (both in depth and width) increases the drawdown. When a vessel moves close to one of the banks, the drawdown will be higher in the region between the vessel and the bank than for the case when it sails along the central line of the channel (Bouwmeester et al.) [9]. Schijf and Jansen [13] developed a method to predict the drawdown from one-dimensional energy and continuity equations. Hochstein and Adams [14] derived the following maximum drawdown formula from Bernoulli's equation:

$D_{d}=\gamma V_{s}^{2}(a-1) \frac{W_{c}}{2 g}$, where $\gamma$ is an empirical constant,

$a=\left(\frac{n}{n-1}\right)^{2.5}$ and $n=A_{c} / A_{s}$

where $n$ is the blockage ratio and $g$ is the acceleration due to gravity. $A_{C}, A_{S}, W_{C}$ and $V_{S}$ are the cross-sectional area of the channel, area of the submerged portion of the vessel, surface width of the channel and vessel speed with respect to ambient flow, respectively. Schijf and Jansen [13] developed a method to predict the drawdown from one-dimensional energy and continuity principles. Gelencser [25] presented an equation for drawdown from prototype and model results. In his formulation the dimension of the vessel, its speed and distance from bank, and channel geometry are considered. The expression for drawdown is given as:

$D_{d}=2 \times 10^{-6}\left[\left(\frac{V_{s}^{2} A_{s} L^{2}}{y \sqrt{A_{c}}}\right)^{1 / 3}\right]^{2.8}$ where $y$ is the distance from sailing line and $L$ is the length of the vessel. Dand and White [26] have given the following formulation of drawdown based on scaled ship model experiments

$D_{d}=8.8\left(\frac{A_{c}}{A_{s}}\right)^{-1.4}\left(\frac{V_{s}^{2}}{2 g}\right)$

The average drawdown across the channel for the 6 events of barge-tow at Kampsville is computed considering the formulations proposed by Hochstein and Adams [14] and by Dand and White [26]; whereas the drawdown at the points $\mathrm{y}=5 \mathrm{~m}$ and $10 \mathrm{~m}$ from barge are computed using the Gelencser [25] formulation. Near the barge, the drawdown becomes maximum and it decreases away from barge, i.e. towards the bank. The average drawdowns are also computed and are given in Table 2. It is found that the order of the drawdown is almost same for each case except at $y=5 \mathrm{~m}$.

\subsection{Squatting}

The prediction of squat depends on ship draft, blockcoefficient, speed, channel depth, cross-sectional area, ambient flow of the river, etc. Squat increases with speed of the vessel for a given water depth and bank proximity. The ship may even strike the channel bed if the speed is increased further. This has been studied by Lap [27] where he considered the work of Krietner [1]. Empirical formulae for bow and stern squats have been proposed by several researchers including Hooft [28], Huuska [29], Barrass [30], Eryuzlu and Hausser [31], Norrbin [32], Romisch [33], Millward [34] and Eryuzlu et al. [35] based on physical model tests and field measurements for different channels, ships and loading characteristics. Barras [30] has given the following squat $\left(S_{q}\right)$ formulation as a function of block coefficient $\left(C_{B}\right)$ and speed of the vessel in knots $\left(V_{k}\right)$ and it has been validated with full scale measurements.

$S_{q}=2 C_{B} \frac{V_{k}^{2}}{100}$

Huuska [29] extended the work of Hooft [28] and introduced a correction factor $K_{S}$ for bow squatting $\left(S_{b H}\right)$ in restricted channels, as follows:

$S_{b H}=2.4 \frac{D_{v} F_{n h}^{2} K_{s}}{L_{p p}^{2} \sqrt{1-F_{n h}^{2}}}$ 
Table 3. Computed Ship Squat for Upstream and Downstream Bound Barge-Tow

\begin{tabular}{|c|c|c|c|c|c|c|}
\hline \multirow{2}{*}{ Barge-Tow } & \multirow{2}{*}{ Direction } & \multicolumn{5}{|c|}{ Squat (m) } \\
\cline { 3 - 8 } & & Huuska (1976) & Barrass (1979) & Eryuzlu et al. (1994) & OCADI (2002) & Average \\
\hline \hline Sugarland & Upstream & 0.13 & 0.08 & 0.06 & 0.13 & 0.10 \\
\hline Conti Karla & Upstream & 0.10 & 0.06 & 0.04 & 0.11 & 0.08 \\
\hline Nicholas Duncan & Upstream & 0.07 & 0.04 & 0.04 & 0.07 & 0.06 \\
\hline W.C. Norman & Downstream & 0.24 & 0.19 & 0.16 & 0.36 & 0.24 \\
\hline Rambler & Downstream & 0.29 & 0.12 & 0.12 & 0.28 & 0.20 \\
\hline Ardyce Randal & Downstream & 0.27 & 0.16 & 0.10 & 0.25 & 0.20 \\
\hline
\end{tabular}

where $D_{v}$ is the ship's displaced volume, $\mathrm{F}_{\mathrm{nh}}$ is the Froude number and $L_{p p}$ is the length between perpendicular of the vessel. The value for $K_{s}$ is determined from

$K_{s}= \begin{cases}7.45 s_{1}+0.76 & \mathrm{~s}_{1}>0.03 \\ 1.0 & \mathrm{~s}_{1} \leq 0.03\end{cases}$

where $s_{1}$ is the blockage factor defined as

$s_{1}=\frac{S}{K_{1}} ; S=\frac{A_{S}}{A_{c}}$

where $K_{1}$ correction factor suggested by Huuska [29]. This squatting formulation is applicable for $F_{n h}$ less than 0.7 . The Overseas Coastal Area Development Institute (OCADI) [36] proposed a new formula for bow squat $S_{b o}$ as

$S_{b O}=\left[\left(0.7+1.5 \frac{T}{h}\right)\left(\frac{C_{B} B}{L_{p p}}\right)+1.5 \frac{T}{h}\left(\frac{C_{B} B}{L_{p p}}\right)^{3}\right] \frac{V_{s}^{2}}{g}$

Eryuzlu et al. [35] proposed a bow squatting $\left(S_{b f}\right)$ formula based on physical model tests and field measurements as

$S_{b E}=0.298 \frac{h^{2}}{T}\left(\frac{V_{s}}{\sqrt{g T}}\right)^{2.289}\left(\frac{h}{T}\right)^{-2.972} K_{b}$

where $h$ is the water depth of the channel, $T$ is the draft of the vessel and $B$ is the beam of the vessel. $K_{b}$ is a correction factor for channel width and is given as

$$
K_{b}=\left\{\begin{array}{ll}
\frac{3.1}{\sqrt{\mathrm{W}_{\mathrm{c}} / \mathrm{B}}} & \frac{\mathrm{W}_{\mathrm{c}}}{\mathrm{B}}<9.61 \\
1.0 & \frac{\mathrm{W}_{\mathrm{c}}}{\mathrm{B}} \geq 9.61
\end{array}\right\}
$$

It is found that the computed squat for the barge-tow movements using Huuska [29] and OCADI [36] formulations produce almost similar results. The Barrass [30] and Eryuzlu et al. [35] formulations also give similar results but with lower values than that of the Huuska and OCADI formulas. All computed squatting values with their average are given in Table $\mathbf{3}$.

\subsection{Lateral Distribution of RF Velocity}

The first critical velocity $\left(V_{c r}\right)$ for the upstream bound barge-tows Sugarland, Conti Karla and Nicholas Duncan, and downstream bound barge-tows W. C. Norman, Rambler and Ardyce Randal are computed using the formula presented by Hochstein and Adams [14]:

$V_{c r}=K\left[\frac{g A_{c}}{W_{c}}\right]^{0.5}$

where $K=$ constrainment factor and is a function of blocking ratio $n=A_{c} / A_{s}$ and the ratio $L / B$. The average backwater flow velocity $V_{r s}$ is calculated using the approach developed by Hochstein [37]

$V_{r s}=V_{s}\left[\left(a B_{F}-B_{F}+1\right)^{0.5}-1\right]$

where $a=\left[\frac{n}{n-1}\right]^{2.5}$ and $B_{F}=0.3 e^{1.8 V_{s} / V_{c r}}$

where $V_{s} / V_{c r} \leq 0.65 ;$ or $B_{F}=1.0$ when $0.65<V_{s} / V_{c r} \leq 1.0$. Hochstein and Adams [14] proposed the following empirical formulation to represent lateral flow velocity

$V_{r H}(y)=k_{1} e^{\left(-y / k_{2}\right)}$

where $V_{r H}(y)$ is the return flow velocity at a distance $y$ from vessel centerline; $k_{l}=V(0)=\alpha V_{r s}$,

$k_{2}=B_{\text {side }} / \alpha\left[1-e^{\alpha F(\alpha)}\right], F(\alpha)=0.42+0.52 \ln \alpha$

where

$\alpha=\max \left\{\begin{array}{l}1 \\ 0.114\left(W_{c} / B\right)+0.715\end{array}\right.$

and $B_{\text {side }}=$ distance from vessel centerline to bank.

Using the formulations of Maynord and Siemen [17], the average return velocity for each side of the vessel $V_{r s}$ can be computed as

$\frac{V_{r s}}{V_{r}}=0.36 S K E W+0.63$

where $V_{r}=V_{s}\left[\left(\frac{n}{n-1}\right)^{1.25}-1\right], V_{s}$ is the ship's speed, $S K E W$ is $A_{c} /\left(2 A_{\text {side }}\right)$ and $A_{\text {side }}$ is the cross-sectional area from the vessel centre line to bank. The ratio $\alpha$ of maximum return 
Table 4. Grid Independency Test

\begin{tabular}{|c|c|c|c|c|c|c|}
\hline \multicolumn{7}{|c|}{ Sugarland Barge-Tow at Kampsville (Upstream Case), Barge Velocity - 1.88 m/s } \\
\hline \multirow[t]{2}{*}{ Points } & \multicolumn{3}{|c|}{ Total Number of Cells (Hexahedral): 372500} & \multicolumn{3}{|c|}{ Total Number of Cells (Hexahedral): 572500} \\
\hline & $10 \mathrm{Sec}$ & $20 \mathrm{Sec}$ & $30 \mathrm{Sec}$ & $10 \mathrm{Sec}$ & $20 \mathrm{Sec}$ & 30 Sec \\
\hline P1 & 0.1899 & 0.2214 & 0.2433 & 0.1887 & 0.2200 & 0.2436 \\
\hline $\mathrm{P} 2$ & 0.1948 & 0.2278 & 0.2500 & 0.1935 & 0.2264 & 0.2505 \\
\hline P3 & 0.2037 & 0.2392 & 0.2616 & 0.2022 & 0.2377 & 0.2621 \\
\hline P4 & 0.2176 & 0.2565 & 0.2781 & 0.2159 & 0.2549 & 0.2789 \\
\hline
\end{tabular}

velocity on each side of the vessel $V_{r s m}$ to $V_{r s}$ is computed from

$$
\frac{V_{r s m}}{V_{r s}}=\alpha=0.24 N_{\text {side }}+0.734
$$

where $N_{\text {side }}=2 A_{\text {side }} / A_{s}$

The velocity distribution from vessel to bank $V_{r M}(y)$ is given by

$$
\frac{V_{r M}(y)}{V_{r s m}}=\exp \left[c\left(\frac{y-B}{B_{\text {side }}-B}\right)\right]
$$

where $\mathrm{c}=1.2(\alpha-1) ; B$ is the beam width of the vessel and $B_{\text {side }}$ is the distance from vessel to bank. The return velocity proposed by Hochestein and Adams [14] is a decreasing function as $y$ increases, that proposed by Maynord and Siemsen [17] is an increasing function.

\section{OPENFOAM BASED SIMULATION}

In the present study, the CFD - based open source code "OpenFOAM ${ }^{\circledR}$ " has been used to simulate various flow conditions. OpenFOAM [22] is an open source software tool based on the control volume concept and its available features are comparable to the major commercial CFD codes. It is a collection of several CFD solvers, which utilize object oriented $\mathrm{C}++$ libraries. OpenFOAM uses command line utilities for pre-processing and post-processing. The $\mathrm{C}++$ class library makes it possible to implement complicated mathematical and physical models as high-level mathematical expressions. This is facilitated by making the high levels of code resemble standard vector and tensor notation as closely as possible.

\subsection{Governing Equations}

The equations considered for simulation are the following equation of continuity and the Navier-Stokes (N-S) equation for incompressible flow

$\operatorname{div} U=0$

$\frac{\partial U}{\partial t}+\operatorname{div}(U U)=-\frac{1}{\rho} \frac{\partial p}{\partial x}+\operatorname{div}(v\{\operatorname{grad}(U)\})+S$

From equation (19) and (20) governing equations for mean flow field, kinetic energy and dissipation of that energy are obtained [22]. Turbulence is modeled using standard $k$ - $\varepsilon$ model to calculate kinetic energy and dissipation of that energy at each cell. PISO (Pressure Implicit Splitting of
Operators) scheme is used to calculate the fluid velocities, pressures in each cell. OpenFOAM utilizes conjugategradient method, with incomplete Cholesky preconditioning (ICCG) to solve symmetric matrices and the Bi-CGSTAB method for asymmetric matrices. The time step is adjusted dynamically and the results are obtained from the inbuilt solver. The solver forms an executable code which accesses case files. The details of programming technique and implementation for complex physical model can be obtained from the work of Jasak et al. [38]. The model utilizes the set of governing equation in time domain in two-dimensional water plane considering the dimension of the barge-tow, channel geometry and flow conditions.

\subsection{Meshing and Boundary Condition}

A structured hexahedral, multi-block grids are generated for this geometry. To validate the model results, grid independency tests are carried out for four locations (P1, P2, P3 and P4) with hexahedral cells varying form 372500 to 572500 for the Sugerland barge-tow near Kampsville with barge velocity $1.88 \mathrm{~m} / \mathrm{s}$. This has been shown in Table 4. Six cases are solved for three upstream and three downstream conditions. It can be noticed that the RF velocity differs only at third decimal places. However, while simulating for various conditions; the total number of hexahedral cells are taken as 572500 . The initial conditions have been considered as $0.58 \mathrm{~m} / \mathrm{s}$ for all the cases.

The inlet condition is specified in terms Dirichlet condition for velocity, kinetic energy, dissipation rate with pressure outlet condition. The inlet velocity is taken as per various cases are considered. At the side boundary, no-slip conditions are applied for the velocity field and zero gradient conditions are applied for other variables. Grid independency tests are carried out for RF velocity with respect to Sugarland barge-tow for the upstream case. Barge velocity is set to $1.88 \mathrm{~m} / \mathrm{s}$. Simulations are carried out for $0 \mathrm{~s}$ to $100 \mathrm{~s}$ at $10 \mathrm{~s}$ intervals. The corresponding flow Reynolds number (Re) and Froude number ( $\mathrm{Fr}$ ) become $7.52 \times 10^{6}$ and 0.41 respectively. The mesh is generated by using OpenFOAM and block meshDict file has been used. The distribution of mesh is uniform throughout the domain and structural mesh (hexahedral type) has been created. Here, incompressible flow solver is used (pimpleDyMFoam). pimpleDyMFoam is basically a transient flow solver for incompressible flow on a moving mesh using the PIMPLE (merged PISO-SIMPLE) algorithm. The time step is computed implicitly which is of the order of $\mathrm{O}\left(10^{-2}\right)$. The open source visualization software Paraview is used to visualize the results. 
Table 5. Critical Velocity of Barge-Tow

\begin{tabular}{|c|c|c|c|c|}
\hline Barge-Tow & Direction & Speed (m/s) & Froude No. & First Critical Velocity (m/s) \\
\hline \hline Sugarland & Upstream & 1.88 & 0.41 & 4.18 \\
\hline Conti Karla & Upstream & 1.70 & 0.38 & 4.48 \\
\hline Nicholas Duncan & Upstream & 1.52 & 0.35 & 4.53 \\
\hline W.C. Norman & Downstream & 2.90 & 0.39 & 4.23 \\
\hline Rambler & Downstream & 2.48 & 0.32 & 4.30 \\
\hline Ardyce Randal & Downstream & 2.36 & 0.30 & 4.00 \\
\hline
\end{tabular}

\section{RESULTS AND DISCUSSION}

Prior to the simulation, critical velocities and Froude numbers for all barge-tows are computed, and these are shown in Table 5. It can be noticed that all barge-tow movements are in the sub-critical range. For the determination of the first critical velocity, the formulation provided by Hochestein and Adams [14] is considered. We consider the centre line of the channel as a sailing line with extended Kampsville cross section. The simulated RF velocity is denoted as $\operatorname{VoF}(y)$. The computed RF velocities from the formulations of Hochestein and Adams [14] and Maynord and Siemsen [17] are also denoted as $V_{r H}(y)$ and $V_{r M}(y)$ respectively. The comparison of RF velocities $V_{r H}(y)$ and $V_{r M}(y)$ with measured and simulated values has been shown in Figs. (3a-c) and Figs. (4a-c) for upstream and downstream bound barge-tows. It can be noticed that $V_{r H}(y)$ decreases gradually from $0.34 \mathrm{~m} / \mathrm{s}$ near the barge to $0.09 \mathrm{~m} / \mathrm{s}$ near the bank and the RF velocity $V_{r M}(y)$ increases marginally from 0.20 $\mathrm{m} / \mathrm{s}$ to $0.23 \mathrm{~m} / \mathrm{s}$ for the Sugarland (Fig. 3a). After analyzing the computed values of $V_{r H}(y)$ and $V_{r M}(y)$, we classify the results in two parts: (i) upstream barge-tows and (ii) downstream bound barge-tows. Figs. (3a-c) show the comparison of computed values of RF velocities for upstream bound barge-tows. From the computed values of RF velocity, we arrive at the following cases: (a) $V_{r H}(y)>V_{r M}(y)$ for $y<0.4$ for the Sugarland (b) $V_{r H}(y)>V_{r M}(y)$ for $y<0.25$ for the ContiKarla and (c) $V_{r H}(y)>V_{r M}(y)$ for $y<0.2$ for the Duncan. However, all the three velocities are of the same order $\left(10^{-1}\right)$. Similarly, for the downstream bound barge-tow movements (Figs. 4a-c), it is noticed that (a) $V_{r H}(y)>V_{r M}(y)$ for $y<0.3$ for the Norman (b) $V_{r H}(y)>V_{r M}(y)$ for $y<0.25$ for the Rambler and (c) $V_{r H}(y)>V_{r M}(y)$ for $y<0.28$ for the Randal. Since the return flow is negative for all downstream bound barge-tows, modulus is used to indicate magnitude of return flow.

We define dimensionless distance $\left(\mathrm{B}_{\text {side }}=\mathrm{y} / 0.5 * \mathrm{~W}_{\mathrm{s}}\right)$ to indicate the distance between the barge and the bank where $B_{\text {side }}=0$ indicates the barge surface and $\mathrm{B}_{\text {side }}=1$ indicates the bank. Figs. (5a) and (b) show velocity vector and velocity contour plots for the Sugarland after 20s. As the bargetow moves along the centerline of the channel, flow field is found to be evenly distributed. Figs. (6a) and (b) show the corresponding velocity vector and velocity contour plots for the Sugarland after 90s. For a moving vessel, the RF profile generated near the bow at the initial time changes with the elapse of time and consequently the hydrodynamic character- istics also change. Although simulations are carried out for all upstream and downstream cases (six events), we report here velocity field only for 20 s and 90 s for the Sugarland barge-tow. It is evident from Fig. (5a) that the onset of return flow takes place after the elapse of $20 \mathrm{sec}$ and continues up to $90 \mathrm{sec}$ as shown in Fig. (6a). The bow wave's generation, the flow of water mass adjacent to the barge-tow along the length and wake flow are also prominent from the Fig. (6a). This flow of water particles relative to the barge-tow is about $2.7 \mathrm{~m} / \mathrm{s}$ according to the Fig. (6b) which matching from the computed values. For $90 \mathrm{~s}$ case, the wake flow is stronger $(2.7 \mathrm{~m} / \mathrm{s})$ than the $20 \mathrm{~s}$ case $(1.0 \mathrm{~m} / \mathrm{s})$ and are shown in Figs. (5b) and (6b). During the entire period of simulation (100s) the Sugarland moves $188 \mathrm{~m}$ and the W.C. Norman moves $290 \mathrm{~m}$ in the forward direction. Fig. (7a) shows RF profiles across the channel for nine locations along the transverse direction for $10 \mathrm{~s}$ to $50 \mathrm{~s}$ with an interval of $10 \mathrm{~s}$ for the Sugarland barge-tow. With the elapse of time, the RF profiles attenuate near the barge-tow but increase along the transverse direction indicating the passing effect. It is interesting to note that the nature of RF profile remains similar in nature after 100 s, corresponding to the 10 s case (Fig. 7b). However, the $\mathrm{RF}$ profile remains lower near the barge and almost becomes linear and higher towards the bank. Fig. (8a) shows RF profiles for downstream condition (W.C .Norman) for similar time intervals and these velocities are found to be negative in contrast to the upstream cases (Fig. 7a). With the further increase of time, i.e., after 60s, the RF profiles shift from positive to negative scale Fig. (8b) and one can obtain the zero velocity point after which flow reversal takes place. The RF velocity profile for 100 s remains negative throughout and never arrives at the zero velocity point. Mazumder et al. [21] discussed the location of the zero velocity point and its locus under hypothetical conditions. The simulated RF velocity $\left(V_{o F}(y)\right)$ at time $t=10 \mathrm{~s}$ for all the six events are compared with the computed values of $V_{r H}(y)$ and $V_{r M}(y)$. This leads to the following inference when the simulated results are compared with the computed values of Maynord and Siemsen [17], denoted by $V_{r M}(y)$ : (a) $V_{o F}(y)>V_{r M}(y)$ for $y<0.5$ for the Sugarland and Conti Karla (b) $V_{o F}(y)>V_{r M}(y)$ for $y<0.35$ for the Duncan (c) $V_{o F}(y)>V_{r M}(y)$ for $\mathrm{y}<0.47$ for the Norman (d) $V_{o F}(y)>V_{r M}(y)$ for $y<0.4$ for the Rambler and (e) $V_{o F}(y)>V_{r M}(y)$ for $y<0.65$ for the Randal. One can observe that $V_{o F}(y)$ follow the same trend as that of $V_{r H}(y)$ (Hochestein and Adamas) [14] for both the upstream and downstream cases but with higher magnitudes. 


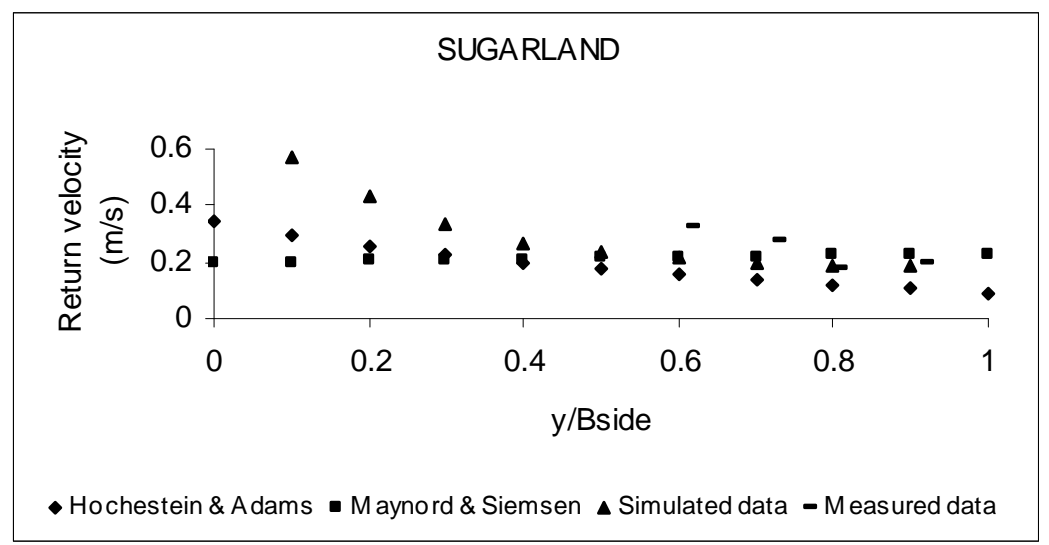

(a)

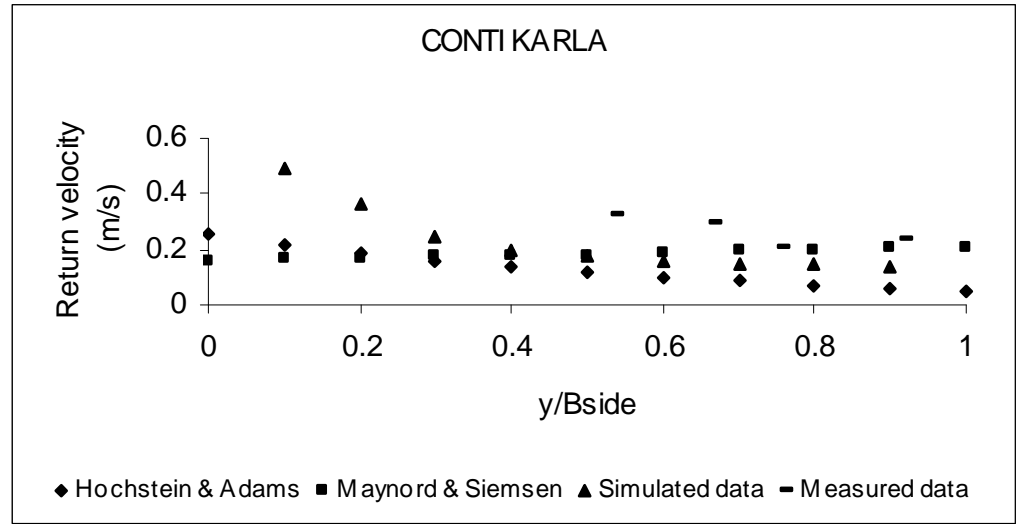

(b)

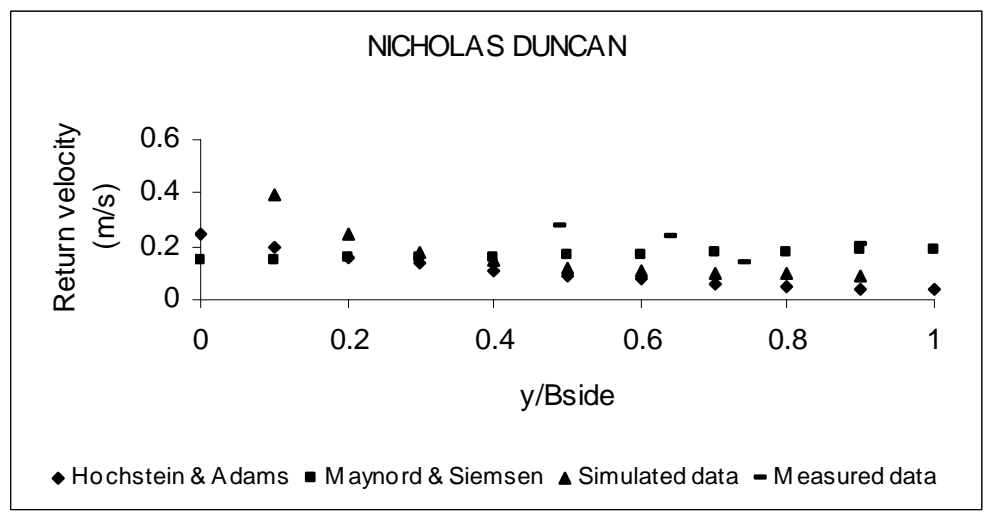

(c)

Fig. (3). Comparison of return velocity profiles between computed and measured for upstream bound barge-tows (a) Sugarland (b) Contikarla and (c) Nicholas Dunkan.

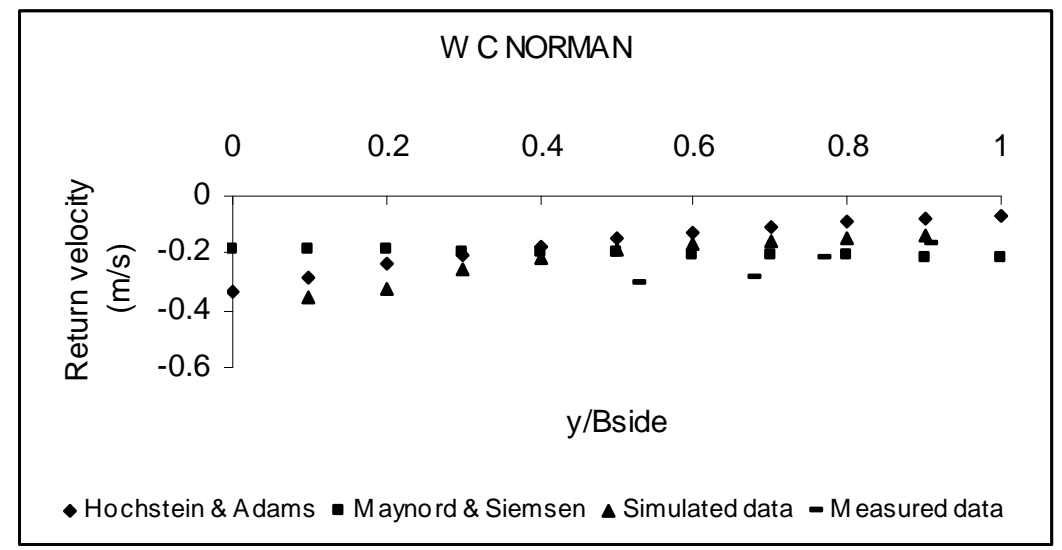

(a) 


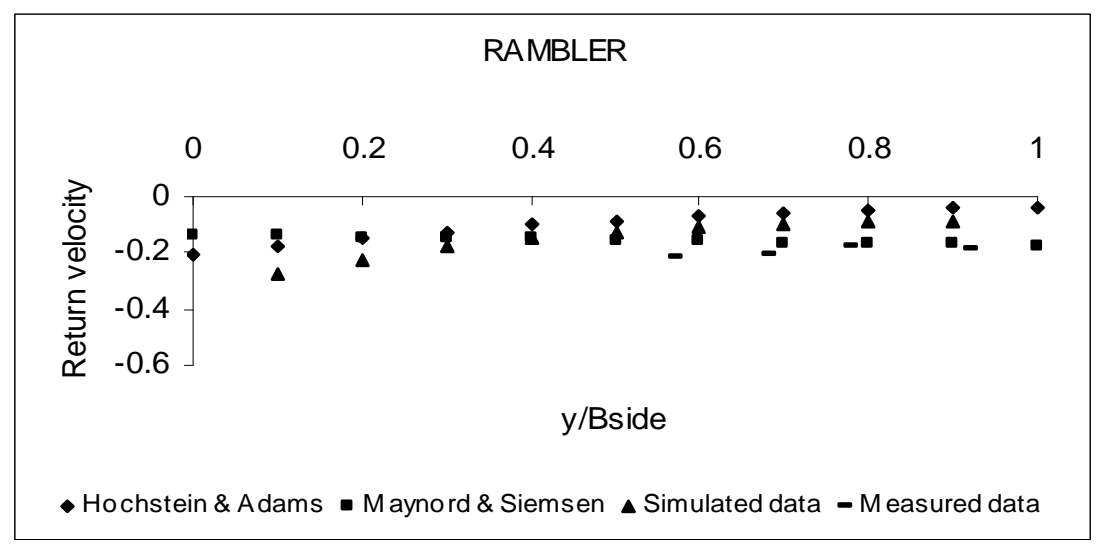

(b)

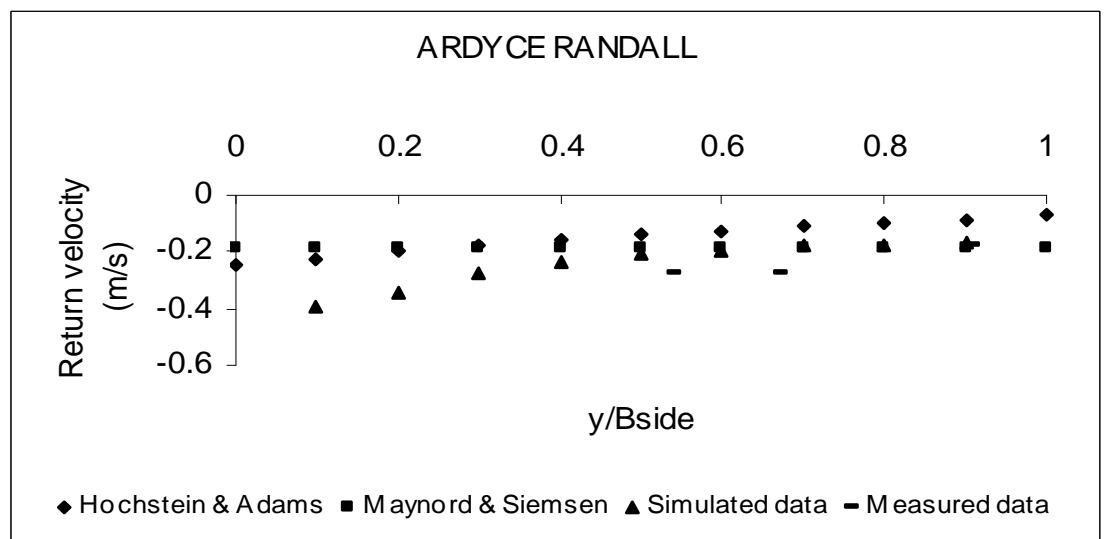

(c)

Fig. (4). Comparison of return velocity profiles between computed and measured for downstream bound barge-tows.

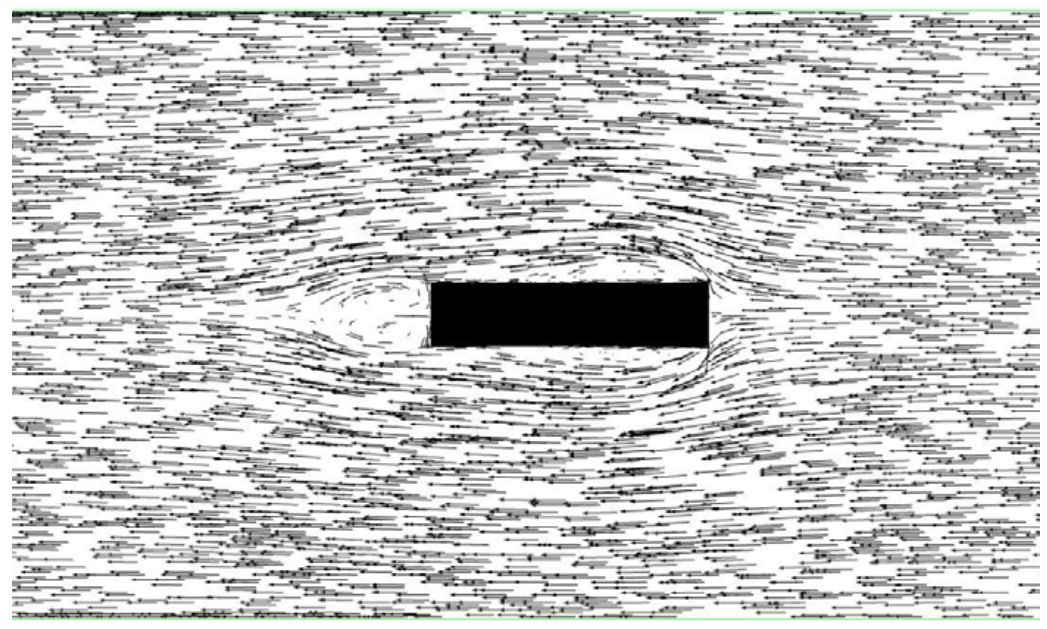

Fig. (5a). Velocity vector plot at $20 \mathrm{sec}$ for Sugarland.

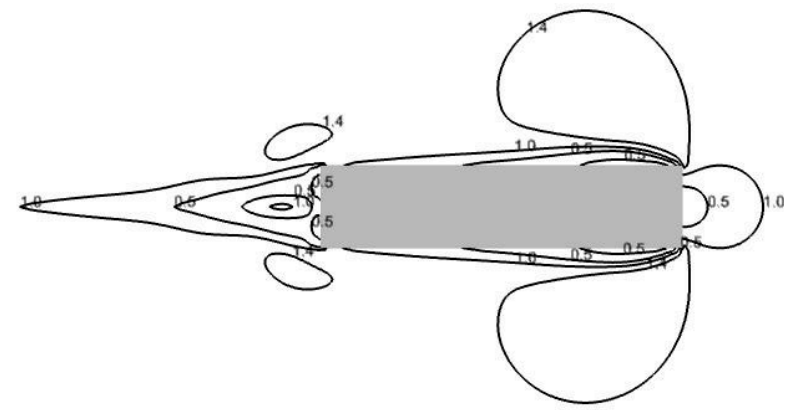

Fig. (5b). Velocity contour plot at $20 \mathrm{sec}$ for Sugarland. 


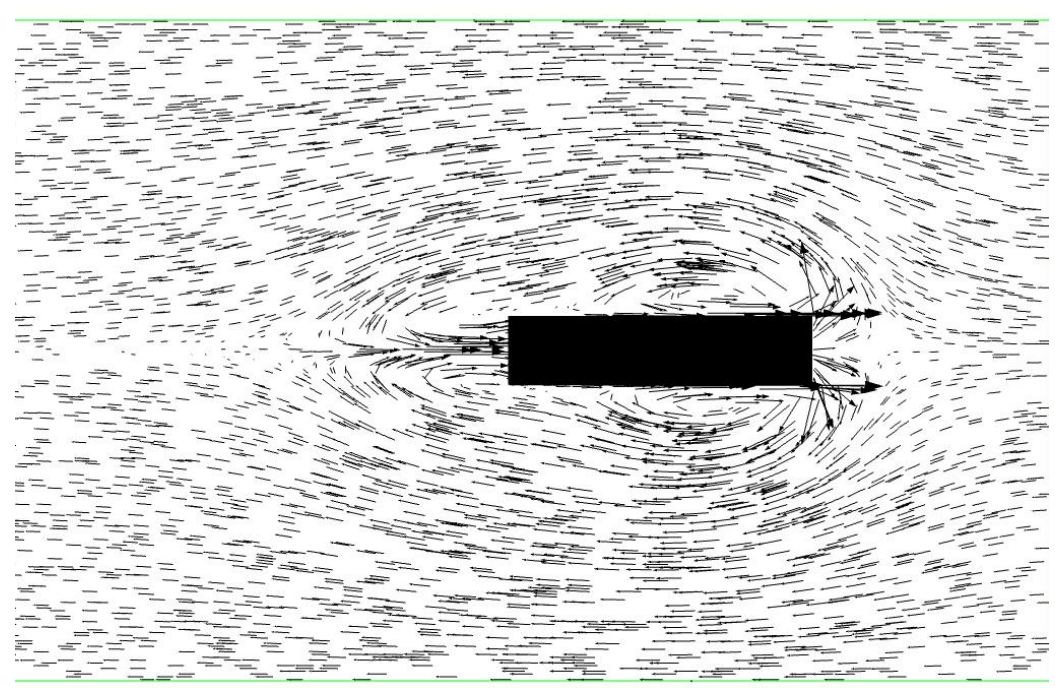

Fig. (6a). Velocity vector plot at $90 \mathrm{sec}$ for Sugarland.

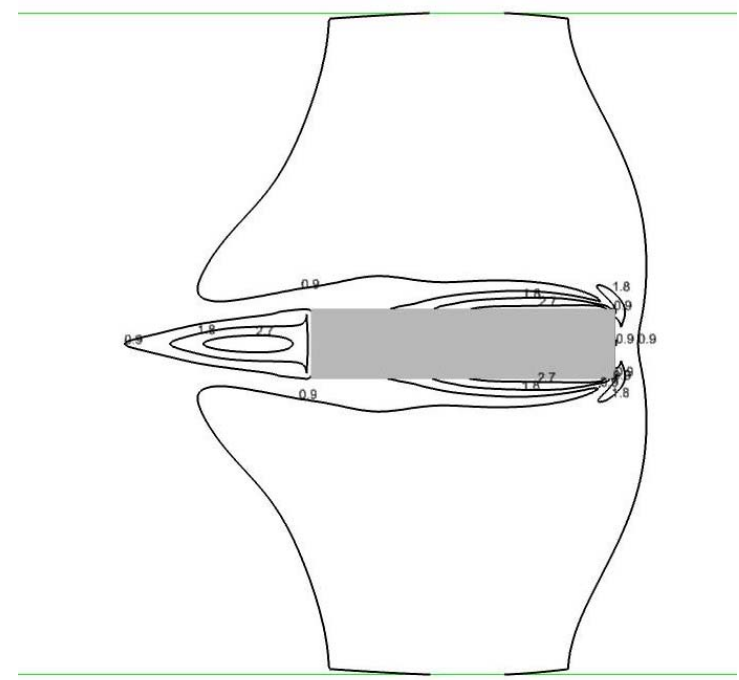

Fig. (6b). Velocity contour plot at $90 \mathrm{sec}$ for Sugarland.

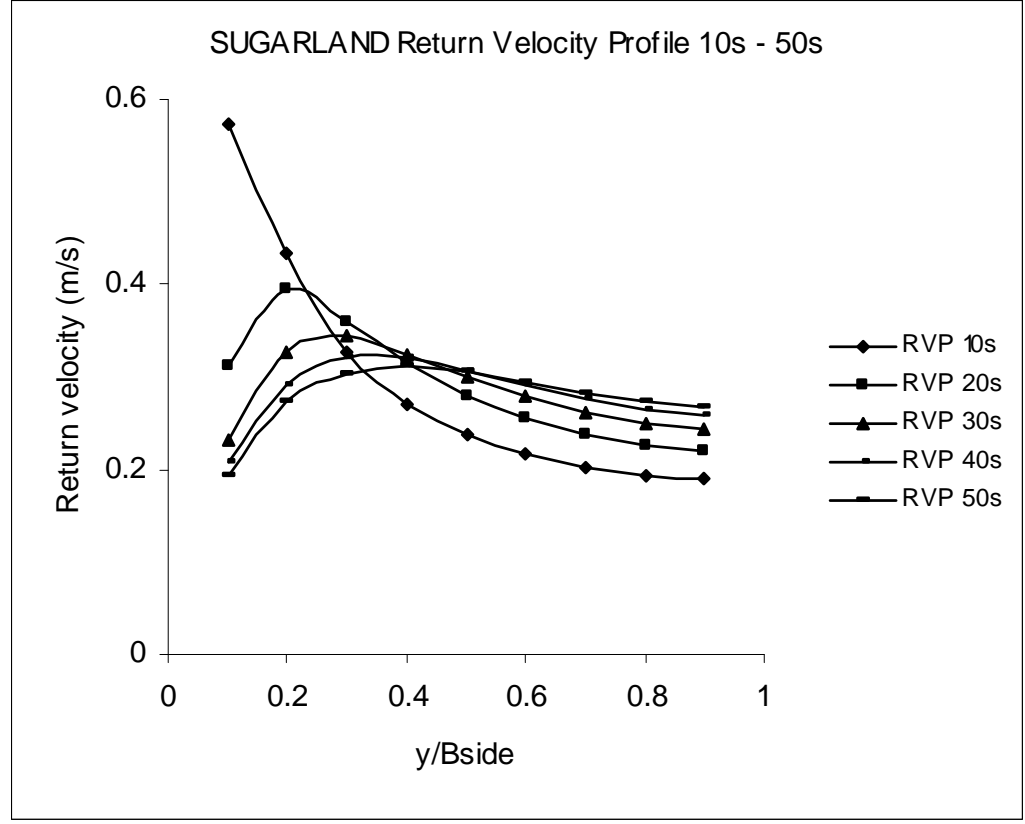

Fig. (7a). Return flow velocity profile (RVP) of Sugarland for $10 \mathrm{~s}$ to $50 \mathrm{~s}$. 


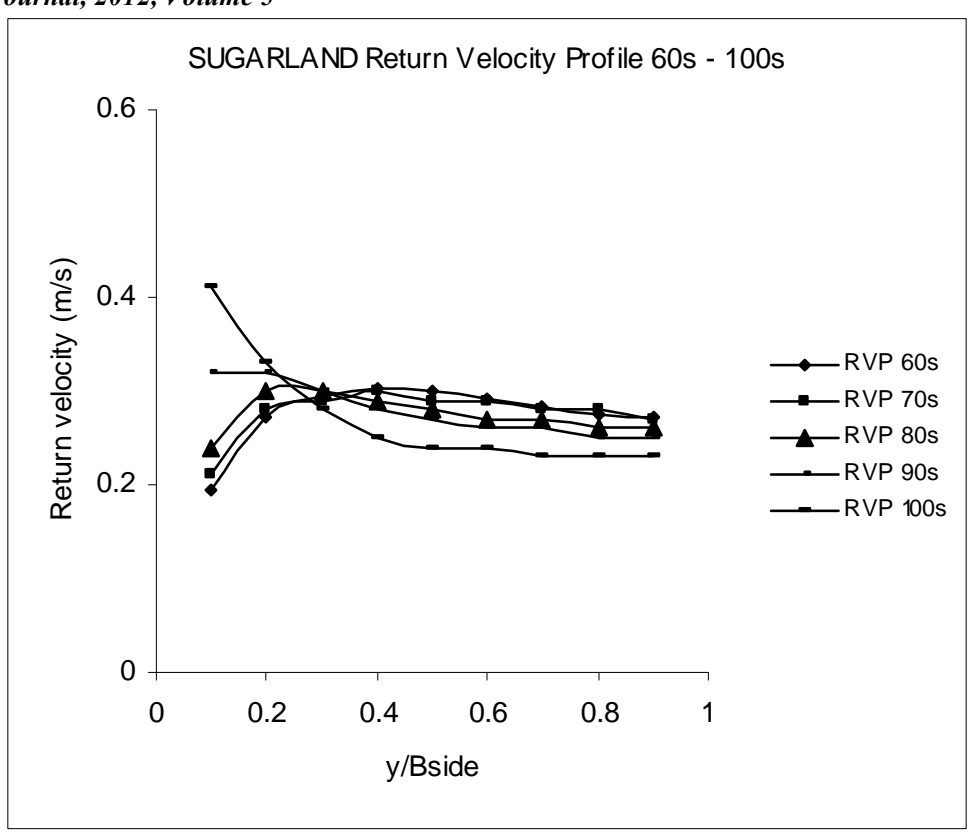

Fig. (7b). Return flow velocity profile (RVP) of Sugarland for 60s to 100 s.

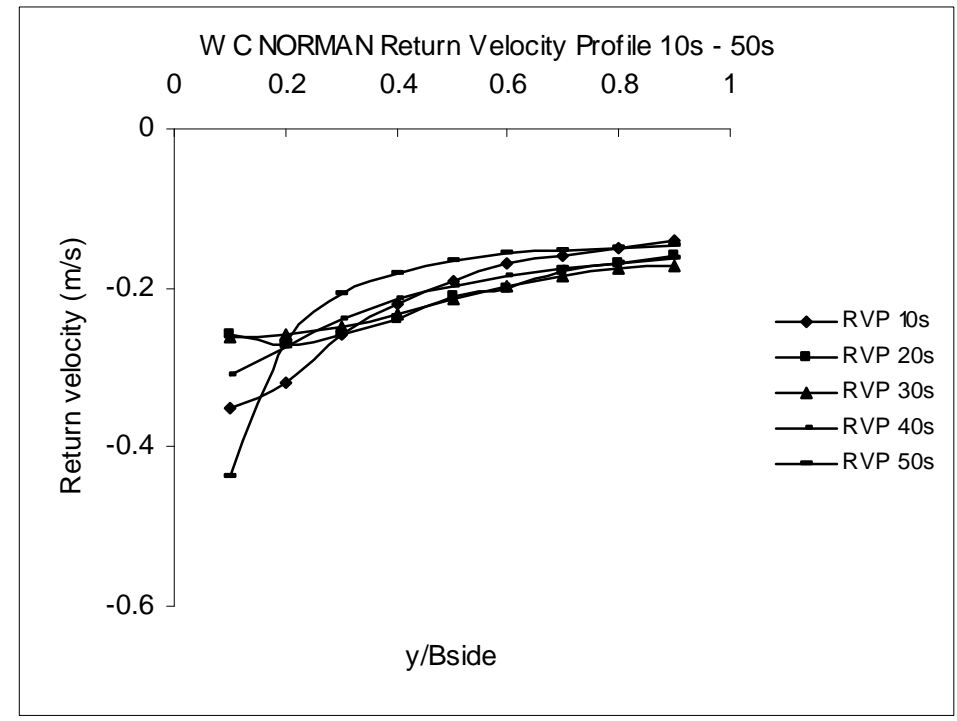

Fig. (8a). Return flow velocity profile (RVP) of W C Norman for 10s to 50s.

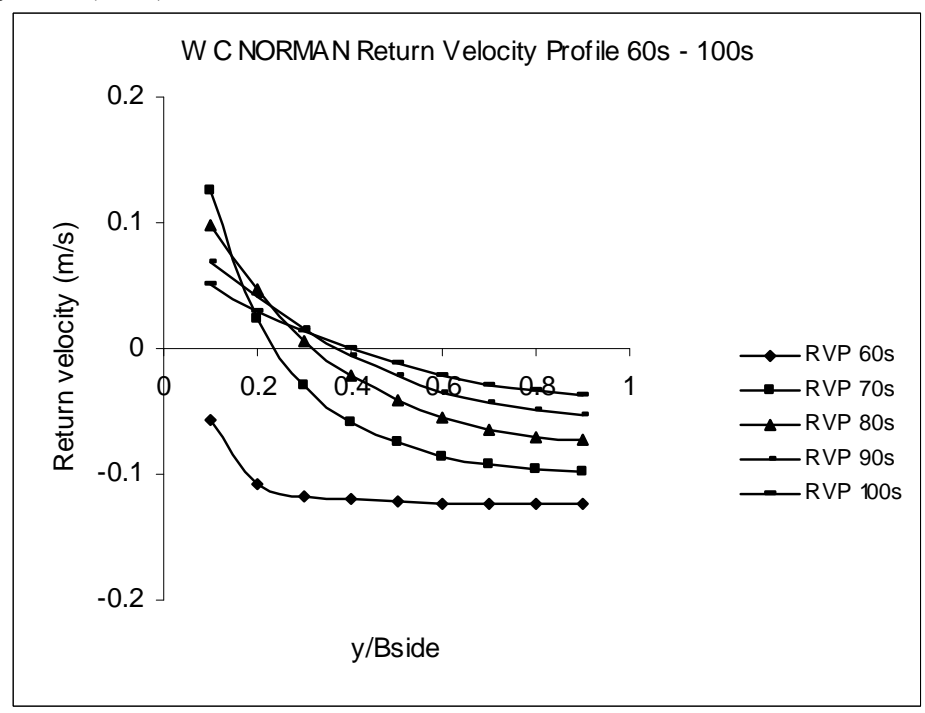

Fig. (8b). Return flow velocity profile (RVP) of W C Norman for 60s to100s. 


\section{CONCLUSIONS}

In this paper, the OpenFOAM model has been used to simulate flow fields for upstream and downstream bound barge-tows for different time instants. The simulated return velocities are analyzed and compared with the observed data near Kampsville on the Illinois River. The barge-tow induced drawdown and squatting are also computed using empirical formulations of various researchers. Overall, the simulated data agree well with the observed return flow data. The simulated result not only describes the magnitude and the complex nature of the return flow patterns but also the location of zero velocity with time. The analysis of computed and simulated data indicates that lower critical speed may be used as speed limits to avert damage of the vessel and the structures at bank, and bank erosion. The present modeling approach can be applied for any restricted waterways. Using this approach, the flow field and return flow patterns for passing barge-tows along a two-lane navigation channel can be simulated, which are usually difficult to measure in the field or in a physical model.

\section{NOTATIONS}

$$
\begin{aligned}
& A_{c} \quad=\quad \text { cross-sectional area of the channel }\left(\mathrm{m}^{2}\right) ; \\
& A_{S} \quad=\quad \text { cross-sectional area of the submerged portion } \\
& \text { of the vessel }\left(\mathrm{m}^{2}\right) \text {; } \\
& A_{\text {side }}=\text { cross-sectional area from vessel centerline to } \\
& \text { bank }\left(m^{2}\right) \text {; } \\
& B \quad=\quad \text { beam of the vessel }(m) \text {; } \\
& B_{\text {side }}=\text { distance from vessel centerline to bank }(m) \text {; } \\
& C_{\mathrm{B}}=\text { block-coefficient; } \\
& \mathrm{D}_{\mathrm{d}} \quad=\quad \text { drawdown height }(m) \text {; } \\
& D_{v} \quad=\quad \text { ship's displaced volume }\left(\mathrm{m}^{3}\right) \text {; } \\
& f \quad=\quad \text { body force }\left(N / m^{3}\right) \text {; } \\
& F_{n h} \quad=\quad \text { Froude number; } \\
& g=\text { Acceleration due to gravity }\left(\mathrm{m} / \mathrm{s}^{2}\right) \text {; } \\
& h \quad=\quad \text { water depth of the channel }(m) \text {; } \\
& K=\text { constrainment factor (function of blocking } \\
& \text { ratio and vessel aspect ratio); } \\
& K 1, K s=\text { correction factors given by Huuska; } \\
& K_{b}=\text { correction factor given by Eryuzlu; } \\
& \mathrm{L}=\quad \text { length of the vessel }(m) \text {; } \\
& L_{p p} \quad=\quad \text { length between perpendicular }(m) \text {; } \\
& n=\text { blockage ratio; } \\
& p \quad=\operatorname{pressure}\left(\mathrm{N} / \mathrm{m}^{2}\right) \\
& \rho=\text { density of water }\left(\mathrm{kg} / \mathrm{m}^{3}\right)
\end{aligned}
$$

$S \quad=\quad$ source term;

$S_{b E} \quad=\quad$ bow squat proposed by Eryuzlu $(m)$;

$S_{b H}=\quad=$ bow squat proposed by $\operatorname{Huuska}(m) ;$

$S_{b O}=$ bow squat proposed by OCADI, Japan $(m)$;

$S_{q} \quad=\quad$ ship squat $(\mathrm{m})$

$s_{1} \quad=\quad$ blockage factor proposed by Huuska;

$t \quad=$ time $(s)$;

$T \quad=\quad$ draft of the vessel $(m)$;

$U \quad=\quad$ velocity vector;

$V_{c r} \quad=\quad$ first critical velocity $(\mathrm{m} / \mathrm{s})$;

$V_{k} \quad=\quad$ vessel speed (knots);

$V_{\text {river }}=$ ambient velocity of the river $(\mathrm{m} / \mathrm{s})$

$V_{r}(y)=$ return flow at the point $y(\mathrm{~m} / \mathrm{s})$;

$V_{r H}(y)=$ return flow at the point $y$ proposed by Hochstein and Adams $(\mathrm{m} / \mathrm{s})$;

$V_{r M}(y)=$ return flow at the point $y$ proposed by Maynord and Siemsen $(\mathrm{m} / \mathrm{s})$;

$V_{r s} \quad=$ average backwater velocity $(\mathrm{m} / \mathrm{s})$;

$V_{r s m}=$ maximum return velocity $(\mathrm{m} / \mathrm{s})$;

$V_{s} \quad=\quad \operatorname{vessel}$ speed $(\mathrm{m} / \mathrm{s})$;

$W_{v} \quad=\quad$ surface width of the channel $(m)$;

$W_{s} \quad=\quad$ cross-sectional area $\left(m^{2}\right)$;

$v=$ kinemetic viscosity $\left(\mathrm{m}^{2} / \mathrm{s}\right)$;

$y=$ distance of the point from the sailing line $(m)$;

$\gamma=$ empirical constant;

div $\quad=$ divergence operator;

grad $=$ gradient;

\section{CONFLICT OF INTEREST}

The authors confirm that this article content has no conflicts of interest.

\section{ACKNOWLEDGEMENT}

Declared none.

\section{REFERENCES}

[1] J. Kreitner, " $\ddot{U}$ ber den Schiffswiderstand auf beschranktem Wasser", Werft Reederei Hafen, Germany, vol. 15, no. 7, pp. 77-82, 1934.

[2] J. B. Schijf, "Section - 1, Communication 2", in XVII International Navigation Congress, Lisbon, 1949, pp. 61-78. 
[3] J. T. Tothill, "Ships in restricted channels - a correlation of model tests, field measurements and theory" The Society of Naval Architects and Marine Engineers, pp. 111-128,1966.

[4] J. S. McNown, "Sinkage and resistance for ship in channels", $J$. Waterway, Harbs, Coast. Eng., ASCE, vol. 102, WW3, pp. 287299, 1976.

[5] T. Constantine, "On the movement of ships in restricted waterways", J. Fluid, Mech., vol. 9, pp. 247-256, 1960.

[6] T. Constantine, "The behaviour of ships moving in restricted waterways", Proc. Inst. Civil Eng., vol. 19, pp. 549-561, 1961.

[7] V. V. Balanin and L. S. Bykov, "Selection of leading dimensions of navigation canal sections and modern methods of bank protection", In: 21st Congress Proceedings, PIANC, Stockholm, 1965, Sections 1-4, pp. 151-169.

[8] B. B. Sharp and J. D. Fenton, "A model investigation of squat", Dock Harbor Auth, no. S77, pp. 242-244, 1968.

[9] J. Bouwmeaster, "Calculation of return flow and water level depression; new method", In: 24 Int. Nav. Congr., SI-3, PIANC, Brussels, Belgium, 1977, pp. 148-151.

[10] R. B. Schofield, "Speed of ships in restricted navigation channels", J. Waterrway. Harbs. Coast. Eng. ASCE, vol. 100, WW2, pp. 133$150,1974$.

[11] H. G. Blaauw and F. M. C. van der Knaap, "Prediction of squat of ships sailing in restricted water", In: $8^{\text {th }}$ Int. Harb. Congr., Delft Hydraulic Lab., Publication No. 302, Delf, The Netherlands, 1983.

[12] N. G. Bhowmik, R. Xia, B. S. Mazumdar, and T. W. Soong, "Return flow in rivers due to navigation traffic", J. Hydr. Eng. ASCE, vol. 121, no. 12, pp. 914-918, 1995.

[13] J. B. Schijf and P. P. Jansen, "Section 1", In: $18^{\text {th }}$ Int. Nav. Congr., Rome, Italy, 1953, pp.175-197.

[14] A. B. Hochstein and C. E. Adams, "Influence of vessel movements on stability of restricted channels", J. Waterway. Port. Coast., Ocean. Eng. ASCE, vol. 115 , no. 5, pp. 444-465, 1989.

[15] D. B. Simons, R. M. Li, Y. H. Chen, S. S. Eillis, and T. P. Chang, "Investigation of effects of navigation traffic activities on hydrologic, hydraulic, and geomorphic characteristics", Report for the Environmental Work Team, Upper Mississippi River Commission Master Plan, Minneapolis, Minnesota, 1981.

[16] L. Berger and Associates, Inc. "Analysis of impact of navigation on the Tennessee Tombigbee Waterway", National Waterways Study Technical Report, Ft. Belvoir, Virginia, 1981.

[17] S. T. Maynord and T. Siemsen, "Return velocities induced by shallow-draft navigation", In: Proc., Hydr. Div./ ASCE Conf., ASCE, New York, NY, 1, 1991, pp. 894-899.

[18] R. L. Stockstill and R. C. Berger, "Simulating Barge Drawdown and Current in Channel and Backwater Areas", J. Waterway. Port. Coast. Ocean. Eng. ASCE, vol. 127, no. 5, pp. 290-298, 2001.

[19] N. G. Bhowmik, D. Soong, J. R. Adams, R. Xia, and B. S. Mazumder, "Physical Changes Associated with Navigation Traffic on the Illinois and Upper Mississippi Rivers", Prepared by Illinois State Water Survey for U. S. Geological Survey, Environmental Management Technical Centre, Onalaska, Wisconsin, LTRMP 98-S001. 205, 1998

[20] N. G. Bhowmik, D. Soong, J. R. Adams, R. Xia, and B. S. Mazumder, "Physical Changes Associated with Navigation Traffic on the Illinois and Upper Mississippi Rivers (Appendices)", Prepared by
Illinois State Water Survey for U.S. Geological Survey, Environmental Management Technical Centre, Onalaska, Wisconsin, LTRMP 98-S001A. Appendices I-XXXII., 1998.

[21] B. S. Mazumder, S. K. Das, and S. N. Das, "Computation of Return flow due to navigation traffics in restricted waterways", Int. $J$. Sediment Res., vol. 21, no. 4, pp. 249-260, 2006.

[22] Open source initiative web pages. Available at http://www.opensource.org, 1987.

[23] B. S. Mazumder, N. G. Bhowmik, and T. W. Soong, "Turbulence and Reynolds stress distribution in natural river", In: Proc., Hydr. Div./ ASCE Conf., ASCE, New York., 1, 1991, pp. 906-911.

[24] B. S. Mazumder, N. G. Bhowmik and T. W. Soong, "Turbulence in rivers due to navigation traffic", J. Hydr. Eng. ASCE, vol. 119, no. 5, pp. 581-597, 1993.

[25] G. J. Gelencser, "Drawdown surge and slope protection, experimental results", In: Proc $24^{\text {th }}$ Int. Nav. Congr, PIANC, Leningrad, Section-1, Subject - 3, 1977, pp. 21-40.

[26] I. W. Dand and W. K. White, "Design of navigation canals", In: Proc Symp Aspects Navigability Constraint Waterways Including Harbour Entrances, Delft, the Netherlands, 1978, vol. 2, Paper No. 3.

[27] A. J. W. Lap, "Fundamentals of ships resistance and propulsion, Part A Resistance", Publication No. 129a of the NSMB, Wageningen, 1950.

[28] J. P. Hooft, "The Behavior of a ship in head waves at restricted water depth", NSS/TNO Report No. 188S, 1974.

[29] O. Huuska, "On the evaluation of underkeel clearances in Finnish waterways", Report No. 9. Otaniemi: University of Technology, Ship Hydrodynamics Laboratory, 1976.

[30] C.B. Barrass, "The phenomena of ship squat", Int. Shipbuilding Progr, vol. 26, pp. 44-47, 1979.

[31] N. E. Eryuzlu and R. Hausser, "Experimental investigation into some aspects of large vessel navigation in restricted waterways", In: Proc. Symp. Aspects Navigability, Delft, 1978, vol. 2, pp. 1-15.

[32] N. H. Norrbin, "Fairway design with respect to ship dynamics and operational requirements", SSPA Research Report No. 102. Gothenburg, Sweden: SSPA Maritime Consulting, 1986.

[33] K. Romisch, "Empfehlungen zur Bemessung von Hafeneinfahrten”, Wasserbauliche Mitteilungen der Technischen Universitat Dresden, Heft 1, pp. 39-63, 1989.

[34] A. Millward, "A preliminary design method for the prediction of squat in shallow water", Mar. Technol., vol. 27, no. 1, pp. 10-19, 1990.

[35] N. E. Eryuzlu, Y. L. Cao, and F. D'Agnolo, "Underkeel requirements for large vessels in shallow waterways", In: $28^{\text {th }}$ Int. Nav Congr., PIANC, Sevilla,1994, Paper S11 2, pp. 17-25

[36] Technical standards and commentaries for port and harbor facilities in Japan, Overseas Coastal Area Development Institute of Japan (OCADI), 2002.

[37] A. B. Hochstein, Navigation use of industrial canals. Water Transportation. Moscow Publishing House: USSR, 1967.

[38] H. Jasak, A. Jemcov, and Z. Tukovic, "A C++ Library for Complex Physics Simulations", International Workshop on Coupled Methods in Numerical Dynamics IUC, Dubrovnik, Croatia, 2007, pp. 120

(C) Das et al.; Licensee Bentham Open.

This is an open access article licensed under the terms of the Creative Commons Attribution Non-Commercial License (http://creativecommons.org/licenses/by-nc/3.0/) which permits unrestricted, non-commercial use, distribution and reproduction in any medium, provided the work is properly cited. 